\title{
Ethnobiology After Four Years of Socioecological Violence
}

\author{
Andrew Flachs ${ }^{1 *}$, Elizabeth A. Olson ${ }^{2}$, John M. Marston ${ }^{3}$, and Maria C. Bruno ${ }^{4}$ \\ ${ }^{1}$ Department of Anthropology, Purdue University, West Lafayette, USA. ${ }^{2}$ Department of History, Sociology, and \\ Anthropology, Southern Utah University, Cedar City, USA. ${ }^{3}$ Department of Anthropology, Boston University, Boston, USA. \\ ${ }^{4}$ Department of Anthropology and Archaeology, Dickinson College, Carlisle, USA. \\ *aflachs@purdue.edu
}

Received January 18, 2021

OPEN ठ ACCESS

Accepted January 19, 2021

Published January 22, 2021

DOI 10.14237/ebl.12.1.2021.1750

Copyright (c) 2021 by the author(s); licensee Society of Ethnobiology. This is an open-access article distributed under the terms of the Creative Commons Attribution-NonCommercial 4.0 International Public License (https://creativecommons.org/licenses/by-nc/4.0), which permits non-commercial use, distribution, and reproduction in any medium, provided the original author and source are credited.

Four years ago, the editors of Ethnobiology Letters (Welch et al. 2016) reaffirmed our scholarly and personal commitments to the diversity of ecological and human life. We hoped that our free, open access publication would continue to provide space for ethnobiologists and scholars in related fields to celebrate disciplinary and epistemological plurality. As a community dedicated to the interdisciplinary study of humans, plants, animals, and ecologies, we did not know then what four years of governance under President Donald Trump would mean for the Society of Ethnobiology and our larger community. But we feared an intensification of violence against Indigenous peoples, the destruction of environments, the commodification of scientific knowledge, and cruelty toward the biological and cultural diversity that defines ethnobiological research and ethics.

It was worse than we feared. Channeled through a harmful rhetoric to return to a past defined by settler colonial greatness, the Trump administration ceaselessly attacked institutions of biological and cultural diversity. Over the past four years, officials from the highest office in the United States sought to ban Muslim migrants, separated families migrating into the United States of America, encouraged violence against Indigenous communities protesting pipeline projects invading their land, failed to act as epidemics of police violence (Peeples 2019) and coronavirus (Kullar et al. 2020) intensified across the country at the disproportionate expense of Black, Indigenous, and communities of color, and supported white supremacist violence including an armed insurrection at the United States Capitol to prevent the certification of Joseph R. Biden Jr.'s presidential electoral college win. Against the backdrop of these overt calls for destruction, the United States withdrew from the Paris Climate Accords. Bureaucracies charged with regulating environmental relationships including the Department of Interior, Environmental Protection Agency, and Department of Agriculture perpetuated the quiet work of structural violence through ecological destruction that disproportionately affects the wellbeing of nonwhite and poor communities. They reduced the Indigenous-led Bears Ears National Monument by $85 \%$, rolled back more than 100 environmental protections, limited how scientists could use research in rulemaking, and granted a stay on regulatory enforcement for polluting industries, including confined animal feeding operations, during the coronavirus pandemic (Brugger 2020; Popovich et al. 2020; Smith 2020). In a fitting symbol of such pointed, cruel violence against the web of life, Florida wildlife authorities are investigating a manatee graffitied with "TRUMP" in block letters (Diaz 2021). These policies of nativism and environmental injustice in the United States emboldened similar ones abroad. Ruling governments in Brazil, Russia, India, China, the United Kingdom, and Poland, to name a few, have also intensified violence against ethnic, religious, biological, political, and cultural life. But in the United States, at least, the administration is leaving.

In spite of these challenges, ethnobiologists continued to stand against the violence of white supremacy, which is antithetical to the core socioecological relationships that define ethnobiology. 
In a critical antidote to the destruction of humanenvironmental relationships, ethnobiologists are working to protect lands and ecosystems against settler colonialism (Black Elk and Baker 2020) and working to strengthen claims to food, seed, knowledge, land, and sovereignty (Armstrong and McAlvay 2019). The Society of Ethnobiology worked quickly to establish the Rapid Assistance Fund for Indigenous Communities and Individuals in Need as we are putting action behind our voiced support of Indigenous, Native, First Nations, and others historically oppressed by colonization. Our members teamed up with local communities to document the true, human-entangled histories of land as a protection against its destruction and exploitation (Lepofsky et al. 2017; Thornton et al. 2019) and interrogated methods for inclusive research (Carlessi 2019; Sullivan et al. 2018), all while working to expand the voices and perspectives we publish in our professional communications (Fowler and Herron 2018): Ethnobiology Letters, the Journal of Ethnobiology, and Contributions in Ethnobiology. The Society has amplified our presence on social media as we work to break down elite academic barriers.

Hard, dedicated work remains ahead to leverage our community of scientists, teachers, practitioners, and observers. We believe there is cause for cautious optimism with the next administration and the emerging commitment in the United States (but also elsewhere) to reversing some of the damage that has been done. The election of Joe Biden and Kamala Harris will not only bring a change in the White House, but also the nation's policies as enacted through federal agencies. Within the new administration, we are particularly looking forward to the work of the first Indigenous person, Deb Haaland (Laguna Pueblo), to hold a cabinet position as Secretary of the Interior, and the influence of scholar of science, technology, and social inequality, Alondra Nelson, as deputy science policy chief. Our members, with much of the United States, are looking to re-establish the Bears Ears National Monument, rescind the Keystone XL pipeline permit, return to a reliance on evidencebased science, and recover from the pandemics that have plagued our country through an effective vaccination campaign and genuine efforts to protect Black and non-white lives.

The momentary victory of removing President Trump from office and ushering in a new administration was made possible by massive grass- roots efforts to get out the vote in communities of color that have long been disenfranchised. Repair and solidarity remain critical for these seeds to thrive. In a year when face-to-face sociality can be deadly, ethnobiology demands that respectful relationships grow between and within academic and community organizations who share a common goal of better understanding diverse experiences of living on Earth. We must continue to grow and listen as a community dedicated to biological and cultural wellbeing, especially in the wake of the COVID-19 pandemic that has forced a reflection on the ongoing importance of multi-generational knowledge grounded in place (Vandebroek et al. 2020). Ethnobiology has always been interdisciplinary and political in its interweaving of cultural and ecological systems. The editors of Ethnobiology Letters look forward to continuing to make space for plural voices by publishing open access research that features methods, perspectives, and reviews that investigate the more-than-human dimensions of our entangled lives.

\section{References Cited}

Armstrong, C. G., and A. C. McAlvay. 2019. Introduction to Special Section on Action Ethnobiology. Journal of Ethnobiology 39:3-13. DOI:10.2993/0278-0771-39.1.3.

Black Elk, L., and J. Baker. 2020. From Traplines to Pipelines: Oil Sands and the Pollution of Berries and Sacred Lands from Northern Alberta to North Dakota. In Plants, People, and Places: The Roles of Ethnobotany and Ethnoecology in Indigenous Peoples' Land Rights in Canada and Beyond, edited by Nancy J. Turner, pp. 137-187. McGill-Queen's Press, Montreal, Canada.

Brugger, K. 2020. Trump Administration Expands Reach of EPA Secret Science Proposal. Science Magazine, March 4, 2020. Available at: https:// www.sciencemag.org/news/2020/03/trumpadministration-expands-reach-epa-secret-scienceproposal. Accessed on January 15, 2021.

Carlessi, P. C. 2019. How to Carry Out a Democratic Ethnobotanical Study. Ethnobiology Letters 10:113119. DOI:10.14237/ebl.10.1.2019.1547.

Diaz, J. 2021. Someone Wrote 'Trump' on a Florida Manatee. The New York Times, January 11, 2021, sec. U.S. Available at: https://www.nytimes.com/2021/ 
01/11/us/florida-manatee-trump.html. Accessed on January 15, 2021.

Fowler, C. T., and S. Herron. 2018. The Long Program for Ethics in Ethnobiology. Ethnobiology Letters 9:1-3. DOI:10.14237/ebl.9.1.2018.1356.

Kullar, R., J. R. Marcelin, T. H. Swartz, D. A. Piggott, R. M. Gil, T. A. Mathew, and T. Tan, on behalf of the Infectious Diseases Society of America Inclusion, Diversity, Access, and Equity Task Force. 2020. Racial Disparity of Coronavirus Disease 2019 in African American Communities. The Journal of Infectious Diseases 222:890-893. DOI:10.1093/infdis/jiaa372.

Lepofsky, D., C. G. Armstrong, S. Greening, J. Jackley, J. Carpenter, B. Guernsey, D. Mathews, and N. J. Turner. 2017. Historical Ecology of Cultural Keystone Places of the Northwest Coast. American Anthropologist 119:448-463. DOI:10.1111/ aman.12893.

Peeples, L. 2019. What the Data Say about Police Shootings. Nature 573:24-26. DOI:10.1038/d41586 -019-02601-9.

Popovich, N., L. Albeck-Ripka, and K. Pierre-Louis. 2020. The Trump Administration is Reversing More Than 100 Environmental Rules. Here's the Full List. The New York Times, October 16, 2020, sec. Climate. Available at: https:// www.nytimes.com/interactive/2020/climate/trump -environment-rollbacks-list.html. Accessed on January 15, 2021.

Smith, A. V. 2020. Trump's Impact on Indian Country over Four Years. High Country News, December 16, 2020. Available at: https:// www.hcn.org/articles/indigenous-affairs-trumpsimpact-on-indian-country-over-four-years. Accessed on January 15, 2021.
Sullivan, A., A. Brewis, and A. Wutich. 2018. Studying Children's Cultural Knowledge and Behaviors Related to Environment, Health, and Food: Methods for Ethnoecological Research with Children. Journal of Ethnobiology 38:276-293. DOI:10.2993/0278-0771-38.2.276.

Thornton, T. F., M. Rudolph, W. Geiger, and A. Starbard. 2019. A Song Remembered in Place: Tlingit Composer Mary Sheakley (Loo) and Huna Tlingits in Glacier Bay National Park, Alaska. Journal of Ethnobiology 39:392-408. DOI:10.2993/ 02780771-39.3.392.

Vandebroek, I., A. Pieroni, J. R. Stepp, N. Hanazaki, A. Ladio, R. R. N. Alves, D. Picking, R. Delgoda, A. Maroyi, T. van Andel, C. L. Quave, N. Y. PaniaguaZambrana, R. W. Bussmann, G. Odonne, A. M. Abbasi, U. P. Albuquerque, J. Baker, S. Kutz, S. Timsina, M. Shigeta, T. P. R. Oliveira, J. A. Hurrell, P. M. Arenas, J. P. Puentes, J. Hugé, Y. Yeşil, L. J. Pierre, T. M. Olango, and F. Dahdouh-Guebas. 2020. Reshaping the Future of Ethnobiology Research after the COVID-19 Pandemic. Nature Plants 6:723-730. DOI:10.1038/s41477-020-0691-6.

Welch, J. R., J. M. Marston, and E. A. Olson. 2016. Plurality in Ethnobiology: A Look Towards 2017. Ethnobiology Letters 7:106-106. DOI:10.14237/ ebl.7.1.2016.861. 